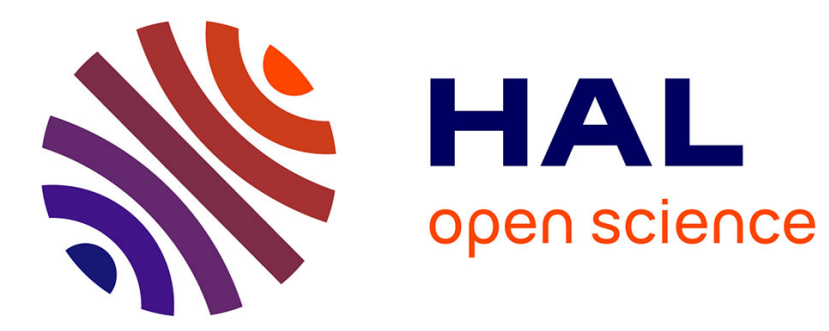

\title{
Laboratory parameters in centenarians of Italian ancestry
}

\author{
C. Caruso, L. Ferito, M. Malaguarnera, D. Maugeri, E. Bennati, L. Scola, D. \\ Lio, M. Motta
}

\section{- To cite this version:}

C. Caruso, L. Ferito, M. Malaguarnera, D. Maugeri, E. Bennati, et al.. Laboratory parameters in centenarians of Italian ancestry. Experimental Gerontology, 2008, 43 (2), pp.119. 10.1016/j.exger.2007.06.005 . hal-00499019

\section{HAL Id: hal-00499019 https://hal.science/hal-00499019}

Submitted on 9 Jul 2010

HAL is a multi-disciplinary open access archive for the deposit and dissemination of scientific research documents, whether they are published or not. The documents may come from teaching and research institutions in France or abroad, or from public or private research centers.
L'archive ouverte pluridisciplinaire $\mathbf{H A L}$, est destinée au dépôt et à la diffusion de documents scientifiques de niveau recherche, publiés ou non, émanant des établissements d'enseignement et de recherche français ou étrangers, des laboratoires publics ou privés. 


\section{Accepted Manuscript}

Laboratory parameters in centenarians of Italian ancestry

C. Caruso, L. Ferito, M. Malaguarnera, D. Maugeri, E. Bennati, L. Scola, D. Lio, M. Motta

PII: S0531-5565(07)00136-2

DOI: 10.1016/j.exger.2007.06.005

Reference: $\quad$ EXG 8356

To appear in: $\quad$ Experimental Gerontology

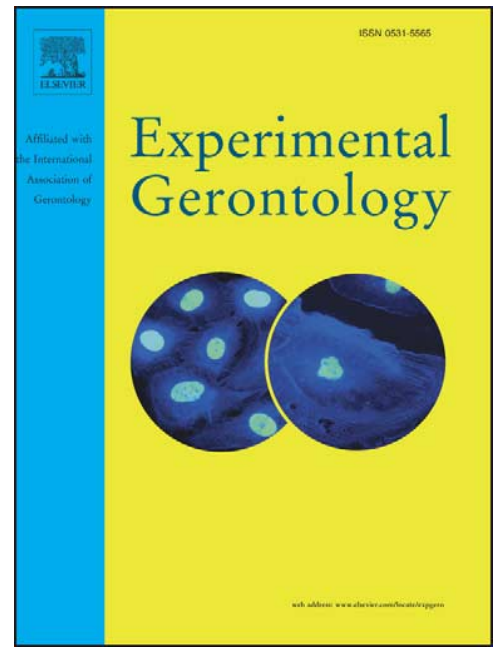

Received Date: $\quad 28$ May 2007

Revised Date: $\quad 21$ June 2007

Accepted Date: $\quad 26$ June 2007

Please cite this article as: Caruso, C., Ferito, L., Malaguarnera, M., Maugeri, D., Bennati, E., Scola, L., Lio, D., Motta, M., Laboratory parameters in centenarians of Italian ancestry, Experimental Gerontology (2007), doi: 10.1016/j.exger.2007.06.005

This is a PDF file of an unedited manuscript that has been accepted for publication. As a service to our customers we are providing this early version of the manuscript. The manuscript will undergo copyediting, typesetting, and review of the resulting proof before it is published in its final form. Please note that during the production process errors may be discovered which could affect the content, and all legal disclaimers that apply to the journal pertain. 


\section{ACCEPTED MANUSCRIPT}

Elsevier Editorial System(tm) for Experimental Gerontology

Manuscript Draft

Manuscript Number: EXG-07-499

Title: Laboratory parameters in centenarians of Italian ancestry

Article Type: Special Issue: Monograph Centenarians

Keywords: laboratory parameters, longevity, healthy centenarians, elderly subjects

Corresponding Author: Prof Calogero Caruso, MD

Corresponding Author's Institution: University of Palermo

First Author: Calogero Caruso, MD

Order of Authors: C. Caruso; L Ferlito; M Malaguarnera; D Maugeri; E Bennati; L. Scola; D. Lio, M Motta

Abstract: Studies aimed at collecting reference parameters for hematochemical analysis in the elderly are scarce and for the oldest old subjects even more rare. In order to establish the reference values for the most common laboratory text in long living individuals, we measured hematochemical parameters in $>100$ years old subjects and in aged subjects as control. 602 centenarians accepted to be enrolled in the study. A case history containing the complete anamnesis, clinical examinations, evaluation of the clinical cognitive and functional tests, was prepared for each centenarian. Blood samples from $120>100$ years old subjects free of chronic or acute Illness (i.e Alzheimer's Disease, Methabolic diseases, Cardiovascular disease, Stroke, neoplastic and infectious diseases) were analysed. A population of 381 healthy old subjects (age range 65-85 years old), recruited in the same geographic areas and with the same clinical characteristic of the health centenarians, was utilized as control. Significant differences were observed for blood glucose, ALT, Cholesterol and Platelet levels, reduced in centenarians respect to the old subjects, whereas blood Urea Nitrogen levels were found significantly increased in centenarians.

In conclusion, reference values of the healthy adults can generally been utilized also for the healthy oldest old group, with the notable exception of the above mentioned laboratory parameters that appear to be modified in long living subjects. 


\section{LABORATORY PARAMETERS IN CENTENARIANS OF ITALIAN ANCESTRY}

C. Caruso $^{\text {a* }}$, L. Ferito ${ }^{b}$, M. Malaguarnera ${ }^{b}$, D. Maugeri ${ }^{b}$, E. Bennati ${ }^{b}$, L. Scola ${ }^{a}$, D. Lio ${ }^{a}$, M. Motta ${ }^{b}$ and IMUSCE**

a Immunosenescence Study Group Department of Biopathology and Biomedical Methodology, University of Palermo, C.so Tukory, 211, I-90134 Palermo, Italy

${ }^{\mathrm{b}}$ Department of Senescence Sciences, University of Catania, Cannizzaro Hospital, Via Messina, 829, I-

95126 Catania, Italy

*Corresponding author: Prof Calogero Caruso, MD

Immunosenescence Study Group

Department of Biopathology and Biomedical Methodology

University of Palermo

C.so Tukory, 211

I-90134 Palermo, Italy

Phone: ++390916555911

Fax: $\quad++390916555933$

E-mail: marcoc@unipa.it

**For IMUSCE see Appendix 1. 


\begin{abstract}
Studies aimed at collecting reference parameters for haematochemical analysis in the elderly are scarce and for the oldest old subjects even more rare. In order to establish the reference values for the most common laboratory text in long living individuals, we measured haematochemical parameters in $>100$ years old subjects and in aged subjects as control. 602 centenarians accepted to be enrolled in the study. A case history containing the complete anamnesis, clinical examinations, evaluation of the clinical cognitive and functional tests, was prepared for each centenarian. Blood samples from $120>100$ years old subjects free of chronic or acute Illness (i.e Alzheimer's Disease, Metabolic diseases, Cardiovascular disease, Stroke, neoplastic and infectious diseases) were analysed. A population of 381 healthy old subjects (age range 6585 years old), recruited in the same geographic areas and with the same clinical characteristic of the health centenarians, was utilized as control. Significant differences were observed for blood glucose, ALT, Cholesterol and Platelet levels, reduced in centenarians respect to the old subjects, whereas blood Urea Nitrogen levels were found significantly increased in centenarians.

In conclusion, reference values of the healthy adults can generally been utilized also for the healthy oldest old group, with the notable exception of the above mentioned laboratory parameters that appear to be modified in long living subjects.
\end{abstract}

Keywords: laboratory parameters, extreme longevity, centenarians, elderly subjects 


\section{Introduction}

Laboratory data are of fundamental importance for the diagnosis, the prognosis and the therapy of various diseases. The interpretation of the obtained data depends on our actual knowledge regarding the pathophysiological mechanisms determining the parameters studied, and their significance in relation with the clinical status of the patient.

During the recent years, the World Health Organization (WHO) has indicated a unique reference range of the results of laboratory examinations, independently from the age of subjects, and sometimes also from the gender. E.g., for the haemoglobin $(\mathrm{Hb})$, independently from the age, pathological values have been established $\leq 13 \mathrm{~g} / \mathrm{dl}$ in males, and $\leq 12 \mathrm{~g} / \mathrm{dl}$ in females, and $>18 \mathrm{~g} / \mathrm{dl}$ for both sexes (Daae et al., 1988; Kelso, 1990; Cavalieri et al., 1992).

These criteria of interpretation are considered only partially acceptable, and the clinical decision thresholds for the pathological conditions are extremely variable depending on age and sex and physiological conditions (i.e. the pregnancy) of each individual. In the elderly it is common to find values of haemoglobin slightly below the established reference parameters of the WHO. This does not necessarily indicate a pathological condition, but could be considered as a secondary phenomenon of the aging process (Carmel, 2001).

In addition, the fasting blood glucose has recently been established to be normal under $126 \mathrm{mg} / \mathrm{ml}$ by the WHO, instead of the previously accepted value of $<140 \mathrm{mg} / \mathrm{dl}$, again independently from the age and gender (The Expert Committee, 1997). This is in contrast with a number of observations made in the elderly, demonstrating that starting from 30 years of age, the fasting and the post-prandium blood glucose ( $1 \mathrm{hr}$ after the meal) have an increase of 2 and $10 \mathrm{mg} / \mathrm{dl}$, respectively, per each further decade of life (Daae et al., 1988; Cavalieri et al., 1992; Hurwitz, 1993).

Therefore, to achieve a correct interpretation of the haematochemical results in the elderly population, the evaluation of organ and system age-related modifications is necessary (McPherson et al., 1978; Kelso, 1990; Cavalieri et al., 1992; Hurwitz, 1993).

The age-dependent changes may influence several laboratory findings, and result in erroneous diagnostic indications. A relevant literature has shown some variability of the results. As a matter of fact, there are some parameters which do not change significantly with age, that is bilirubin, alanine-aminotransferase (ALT), aspartate-aminotransferase (AST), gamma-glutamyl-transpeptidase (GGTP), thyroxin (T4), but other parameters could have reduced values, such as serum proteins, vitamin B12, three-iodium-thyronine (T3), thyrotropin (TSH), high-density lipoprotein (HDL)-cholesterol, or even increased values, such as erythrocyte sedimentation rate (ESR), total cholesterol, triglycerides, alkaline phosphatase (ALP) (McPherson et al., 1978; Tietz et al., 1992). The value of ALP seems to be more increased in females than in males (Kelso, 1990; Cavalieri et al., 1992). The ESR increases with age as a consequence of anemia, and chronic-degenerative pathologies, being frequent in the elderly. It may reach values up to $40 \mathrm{~mm} / 1 \mathrm{st} \mathrm{hr}$ in males and $45 \mathrm{~mm} / 1 \mathrm{st} \mathrm{hr}$ in females (Sharland, 1980; Brigden, 1998).

The serum creatinine values are correlated with the muscular metabolism. Since the muscular mass is reduced in the elderly, this compromises the use of this parameter as an indicator of the renal functions in the elderly. On the other hand, as an indicator of the renal functions, one can better use the creatinine clearance, which is reduced in the elderly (Daae et al., 1988; Cavalieri et al., 1992).

The amount of available data related to haematochemical parameters of oldest old subjects are still scarce, and usually they are embedded in epidemiological studies, containing relatively low numbers of cases. The most important aspect of such studies is that they are not related to the analysis of samples selected on the basis of rigorous clinical criteria. Previous studies performed on centenarian population have revealed, with some conflicting results, that some haematochemical parameters increase (blood glucose, the C-reactive protein $=\mathrm{CRP}$ ), while others decrease (serum albumin, total proteins, red cells, haemoglobin), if compared to the reference values of the adult subjects (Hirose et al., 2000). 
As regards the lipid analysis in centenarian populations, contrasting results have been revealed too. There are findings about decreased or increased values of total cholesterol, LDL- and HDL-cholesterol, triglycerides, ApoB100, ApoB100/ApoA1 and ApoA1. As regards the serum levels of the lipoprotein(a) $(\operatorname{Lp}(\mathrm{a}))$, increased or unchanged values have been observed (Malaguarnera et al., 1998; Toshaki, 1999).

Considering all these conflicting data, the pourpose of this study was to reveal possible modifications of the haematochemical parameters in oldest old subjects possibly to establish a more reliable range of the haematochemical parameters for oldest old people.

Therefore, we studied a numerically adequate sample of healthy centenarians and old persons evaluated with the same epidemiological criteria and clinical approach. 


\section{Subject and methods}

Our sample consisted of 602 centenarians, from many regions of Italy. They were part of the epidemiological studies of the IMUSCE (1997), with the following characteristic: Selection of all >100 years old living persons was obtained using the demographic lists of the registry office kept by all the Italian municipalities involved in the study. From a total population of 14,274,591 inhabitants, 1173 potentially eligible centenarians (202 males and 971 females) were found. The male/female ratio was 1/4.8. The birth date of centenarians was initially checked by matching information from the Census registry, the Baptism Registry of the local Catholic Church, the social security document, and the testimony of a firstdegree relative. We were able to interview 650 centenarian subjects with a substantial unchanging frequency regarding the centenarian population percentage stratified for geographical area and the male/female ratio. The families of centenarians were contacted directly or through the family physician. From the originally identified 650 subjects, 602 accepted to be enrolled in the study. A case history containing the complete anamnesis, clinical examinations, evaluation of the clinical cognitive and functional tests, was prepared for each centenarian. This allow us to identify 120 subjects free of chronic or acute Illness (i.e Alzheimer's Disease, Methabolic diseases, Cardiovascular disease, Stroke, neoplastic and infectious diseases). Each subject underwent a fasting blood sampling, and the blood samples analysed for the following Haematochemical Parameters: Glucose, Urea Nitrogen, Creatinine, Aspartate Transaminase (AST), Alanine Transaminase (ALT), Total cholesterol, HDL-cholesterol, Triglycerides, Uric acid, Total proteins, Albumin, Red Blood Cells, Haemoglobin, White Blood Cells and Platelets. As this was a multicentric study different methodologies and analytical automatic devices were used by the different collaborating group. To allow a normalisation of the obtained values and analytic units used 100 random collected blood samples were shared among the different laboratories and conversion factors were calculated. A population of 381 healthy old subjects (age range 65-85 years old), recruited in the same geographic areas and with the same clinical characteristic of the 120 centenarians, was utilized as control. Written informed consent for enrolling in the study and for personal data management was obtained from all the subjects according to Italian laws.

Unpaired Student's t test was used to evaluate the difference of haematochemical parameters between the two group of Subjects, using GraphPad InStat version 3.06, GraphPad Software statistical package, San Diego California USA. Differences were considered statistically significant when $\mathrm{p}<0.05$.

\section{Results}

The list of laboratory parameters studied is presented in Table 1. The mean values of the laboratory parameters and the obtained range values of all centenarians were compared with those of all elderly subjects (Tab.1). This study was aimed at evaluating the dependence of the laboratory parameters on the age of the subjects and in particular to individuate a range of values for the most common laboratory parameters useful as references values for $>100$ years old subjects of the Italian ancestry. Almost all the investigated parameters resulted similar between the two groups of subjects. Remarkable significant differences were observed for blood glucose, ALT, Total Cholesterol and Platelet levels, reduced in centenarians respect to the old subjects, whereas blood Urea Nitrogen levels were found significantly increased in centenarians.

\section{Discussion}

Gender differences and age trends are considered the major factors influencing the so called "Biological Variability" have been amply documented to characterize blood laboratory parameters. In particular Total cholesterol, Urea Nitrogen, Creatinine and Blood cell levels are strongly influenced by aging processes (Lapin and Bohmer, 2005) . in this paper we have compared data from 120 healthy centenarians and 381 younger subjects aiming to evaluate if extreme longevity might influence the laboratory reference parameter distribution in subjects $>100$ years old. 
The major part of laboratory values are very similar among the subjects of the two group. Nevertheless some significant differences were found. As expected Urea Nitrogen Levels show an age related increase (Tietz et al., 1992) according to the age related progressive reduction of kidney functionality and increased protein katabolism. The lower values of platelets in the population of centenarians, when compared to the elderly sample, should be undertaken as reference values. This finding is probably due to the slowing down of the haematopoietic system activity during aging being reduction of platelet lineage one of the most sensitive marker of an incoming bone marrow failure (Wu et al., 2003). The significantly reduced levels of blood glucose, ALT and Total Cholesterol confirm the major role that the metabolic syndrome plays in determining life span expectancy in general population (Ravaglia et al., 2006), on the other hand reduced cholesterol and glucose blood levels might be related to the relative reduction of food intake that characterise extreme ageing being a frequent cause of a progressive malnutrition. The concept of the metabolic syndrome as a condition that included increased risk for cardiovascular disease, diabetes, and allcause mortality has existed for at least eight decades, but internationally recognized diagnostic criteria are continuously evolving (Eckel et al., 2005; Ford, 2005). More recently, ALT increase have been found associated with insuline resistance (IR) when included in models with waist, metabolic syndrome, hypertriglyceridemic waist, elevated $\mathrm{Tg} / \mathrm{HDL}$, or Homeostatic model assessment (HOMA) IR (Hanley et al. 2007). So the addition of of ALT to existing clinically-based metabolic risk definitions has been recommended as an inexpensive way to improve the identification of subjects with IR (Hanley et al. 2007). In conclusion, our data seem to strongly suggest that the major part of hematochemical parameters were not significantly different between centenarians and elderly individuals. The observed differences could be related both to the aging processes and health status. The wide differences found between the reference values of centenarians in good health and those of old subjects should be mostly referred to the role that genetic and environmental factors play in protecting exceptional individuals as healthy centenarians against the major aging related diseases (Candore et al. 2006). 


\section{References}

Brigden, MR., 1998. The erythrocyte sedimentation rate: still a helpful test when used judiciously. Postgrad. Med. 103, 257-274.

Candore, G., Balistreri, C.R., Listì, F., Grimaldi, M.P., Vasto, S., Colonna-Romano, G., Franceschi, C., Lio, D., Caselli, G., Caruso, C., 2006. Immunogenetics, Gender, and Longevity. Ann. NY Acad. Sci., 1089, 516-537.

Carmel, R., 2001. Anemia and aging: an overview of clinical, diagnostic and biological issue. Bloob Rewiews, 15, 9-18.

Cavalieri, T.A., Chopra, A., Bryman, P.N., 1992. When outside the norm is normal: interpreting lab data in the aged. Geriatrics 47, 66-70.

Daae, L.N., Halvorsen, S., Mathisen, P.M., Mironska, K., 1988. A comparison between haematological parameters in "capillary" and venous blood from healthy adults. Scand. J. Clin. Lab. Invest. 48, 723726.

Eckel, R.H., Grundy, S.M., Zimmet, P.Z., 2005. The metabolic syndrome. Lancet, 365, 1415-1428.

Ford, E.S., 2005. Risks for all-cause mortality, cardiovascular disease, and diabetes associated with the metabolic syndrome. Diabetes Care 28, 1769-1778.

Glantz, S. A., 1994. Programme of Statistical Analysis for Biomedical disciplines. McGraw-Hill.

Hanley, A.J., Wagenknecht, L.E., Festa, A., D'Agostino, R.B. Jr, Haffner, S.M., Apr 11, 2007. Alanine Aminotransferase (ALT) and Directly Measured Insulin Sensitivity in a Multi-ethnic Cohort The Insulin Resistance Atherosclerosis Study. Diabetes Care [Epub ahead of print].

Hirose, N., Suzuki, M., Arai, Y., Nakazawa, S., 2000. Correlates of Nutritional Status in Japanese Centenarians From Facts, Research and Intervention in Geriatrics. Autonomy Versus Dependence in The Oldest Old. Sedi Publisher, Paris, pp. 61-76.

Hurwitz, J., 1993. Interpreting laboratory tests in the elderly. Clin. Biochem. 26, 433-434.

IMUSCE (The Italian Multicentric Study on Centenarians), 1997. Epidemi-ological and socioeconomic aspects of Italian centenarians. Arch. Geron-tol. Geriatr. 25, 149-157.

Kelso, T., 1990. Laboratory values in the elderly: Are they different? Emerg. Med. Clin. North Am. 8, 241-254.

Lapin, A., Bohmer, F., 2005. Laboratory diagnosis and geriatrics: more than just reference intervals for the elderly. Wien Med. Wochenschr., 155, 30-5.

Malaguarnera, M., Giugno, I., Ruello, P., Rizzo, M., Panebianco, M.P., Pistone, G., Tomasello, F.B., 1998. Lipid profile variations in a group of healthy elderly and centenarians. Eur. Rev. Med. Pharmacol. Sci. 2, 75-79.

McPherson, K., Healy, M.J., Flynn, F.V., Piper, K.A., Garcia-Webb, P., 1978. The effect of age, sex and other factors on blood chemistry in health. Clin. Chim. Acta 84, 373-397.

Ravaglia, G., Forti, P., Maioli, F., Bastagli, L., Chiappelli, M., Montesi, F., Bolondi, L., Patterson, C., 2006. Metabolic Sindrome - Prevalence and prediction of mortality in elderly individuals. Diabetes Care, 29, 2471-2476.

Sharland, D.E., 1980. Erythrocyte sedimentation rate: The normal range in the elderly. J. Am. Geriatr. Soc. $28,346-348$.

The Expert Committee on the Diagnosis and Classification of Diabetes Mellitus, 1997. Report of the Expert Committee on the Diagnosis and Classification of Diabetes Mellitus. Diabetes Care, 20, 11831197.

Tietz, N.W., Shuey, D.F., Wekstein, D.R., 1992. Laboratory values in fit aging individuals sexagenarians through centenarians. Clin. Chem., 38, 1167-1185.

Toshaki, I., 1999. Standard results of various physicial examinations of centenarians in Japan from Japanese centenarians. In:. Tauchi, H., Sato, T., Watanabe, T. (Eds.), Medical Research for the Final Stage of Human Aging. Aichi, Japan: Editorial and Publishing Office of Japanese Centenarians, pp. 54-68. 


\section{ACCEPTED MANUSCRIPT}

Wu, H.H., Talpaz, M., Champlin, R.E., Pilat, S.R., Kurzrock, R., 2003. Sequential interleukin 3 and granulocyte-macrophage-colony stimulating factor therapy in patients with bone marrow failure with long-term follow-up of responses. Cancer 98, 2410 - 2419

**Appendix 1.

The Italian Multicenter Study on Centenarians (IMUSCE)

Coordinators: M. Motta, C. Franceschi, L. Motta

List of participants of IMUSCE:

University of Bari: A. Capurso, F. Panza, V. Solfrizzi, A. D’Introno, A.M. Colacicco, S. Capurso

University of Bologna: M. Capri, S. Salvioli, S. Valensin.

University of Catania: M. Malaguarnera, E. Bennati, L. Ferlito, A. Franzone, R. Rapisarda

University of Cosenza: G. De Benedictis, M. Berardelli

University of Firenze : G. Masotti, E. Petruzzi, I. Petruzzi, P. Pinzani, F. Mantelacchi, M. Pazzagli, F.M.

Antonini

University of Foggia: C. Capurso University of Messina: V. Nicita-Mauro, C. Lo Balbo, A. Mento, C. Nicita-Mauro, G. Maltese, G. Basile

University of Milano: D. Mari, R. Coppola, R. Provengano

University of Modena: G. Salvioli, M.V. Baldelli, C. Mussi

University of Napoli : M. Varricchio, M. Barbieri, A. Gambardella, G. Paolisso

University of Palermo: G. Candore, C. Caruso, G. Colonna-Romano, D. Lio, L. Scola

University of Parma: P. Sansoni, R. Vescovini, C. Biasini, F. Zanni, L. Zanlari, A. Telera, G. Lucchini, G. Passeri, M. Passeri

University of Pavia: E. Ferrari, L. Cravello, L. Barili., S.B. Solerte, M. Fioravanti, F. Magri, F. Fagnoni

University of Perugia: U. Senin, P. Mecocci, A. Cherubini

University of Roma "La Sapienza": V. Marigliano, L. Tafaro, P. Cicconetti, F. Tombesi, M.T. Tombolillo, E. Ettore

University of Siena : S. Forconi, S. Boschi, G.A. Righi, M. Guerrini

University of Trieste: L. Giarellit, G. Stanta

National Institute on Aging, National Institutes of Health, Baltimore, Bethesda, MD (USA): L. Ferrucci, A. Ble, EJ. Metter, J M. Guralnik

Istituto Superiore di Sanità, Department of Pharmaca, Roma: R. Pacifici, P. Zuccaro, I. Palmi

Local Sanitary Unit No.3, Operative Unit of Geriatrics, Acireale (CT): S. Branca, M. Passamonte, M. P. Gargante, C. Risino

Local Sanitary Unit No.6, Azienda Ospedaliera dei Bianchi, Corleone (PA): G. Fradà.

Physiotherapist: F. Motta

Laboratory technician: G. Crimi

All the listed participants of this study have contributed to the identification of cases, elaboration and compilation of the clinical records, to collection and evaluation of the data, therefore, the present work is the result of an intense collegial activity. We declare that all participants of IMUSCE have equal merits in all parts of this work. 


\section{ACCEPTED MANUSCRIPT}

Table 1. Haemachemical parameters of 501 health old subjects (120 centenarians and $381<85$ and $>65$ years old subjects)

\begin{tabular}{|c|c|c|c|c|c|}
\hline Parameters, units & \multicolumn{2}{|c|}{ healthy Centenarians } & \multicolumn{2}{|c|}{ Healthy old subjects } & $\mathrm{p}$ \\
\hline & Mean \pm SD & range & Mean \pm SD & range & \\
\hline $\begin{array}{l}\text { Glucose } \\
\mathrm{g} / \mathrm{L}\end{array}$ & $0.84 \pm 0.12$ & $0.72-0.97$ & $0.96 \pm 0.16$ & $0.75-1.18$ & $<0.001$ \\
\hline $\begin{array}{c}\text { Urea Nitrogen } \\
\text { g/L }\end{array}$ & $0.52 \pm 0.18$ & $0.34-0.70$ & $0.37 \pm 0.09$ & $0.20-0.68$ & $<0.001$ \\
\hline $\begin{array}{c}\text { Creatinine } \\
\mathrm{mg} / \mathrm{L}\end{array}$ & $12.9 \pm 4.0$ & $9.0-17.0$ & $8.0 \pm 2.0$ & $5.0-13.0$ & NS \\
\hline $\begin{array}{l}\text { AST } \\
\mathrm{U} / \mathrm{L}\end{array}$ & $23.3 \pm 7.9$ & $5.4-31.2$ & $21.0 \pm 9.0$ & $9.0-43.0$ & NS \\
\hline $\begin{array}{l}\text { ALT } \\
\mathrm{U} / \mathrm{L}\end{array}$ & $13.35 \pm 7,7$ & $5.7-21.0$ & $39.1 \pm 13.6$ & $23.0-55.0$ & $<0.001$ \\
\hline $\begin{array}{c}\text { Total cholesterol } \\
\text { g/L }\end{array}$ & $1.89 \pm 0.36$ & $1.53-2.25$ & $2.16 \pm 0.37$ & $1.67-2.63$ & $<0.001$ \\
\hline $\begin{array}{c}\text { HDL-cholesterol } \\
\mathrm{g} / \mathrm{L}\end{array}$ & $0.57 \pm 0.12$ & $0.45-0.68$ & $0.61 \pm 0.15$ & $0.36-0.85$ & NS \\
\hline $\begin{array}{c}\text { Triglycerides } \\
\text { g/L }\end{array}$ & $1.06 \pm 0.41$ & $0.64-1.47$ & $1.03 \pm 0.67$ & $0.29-2.58$ & NS \\
\hline $\begin{array}{l}\text { Uric acid } \\
\mathrm{mg} / \mathrm{L}\end{array}$ & $56.0 \pm 14.0$ & $42-70$ & $46 \pm 12$ & $29-77$ & NS \\
\hline $\begin{array}{c}\text { Total proteins } \\
\mathrm{g} / \mathrm{L}\end{array}$ & $71.1 \pm 5.6$ & $65-77$ & $68.9 \pm 8.7$ & $55-71$ & NS \\
\hline $\begin{array}{l}\text { Albumin } \\
\mathrm{g} / \mathrm{L}\end{array}$ & $38.4 \pm 4.9$ & $34-59$ & $35.1 \pm 6.5$ & $29-52$ & NS \\
\hline $\begin{array}{c}\text { Red Blood Cells } \\
10^{12} / \mathrm{L}\end{array}$ & $4.24 \pm 0.48$ & $3.7-4.7$ & $4.6 \pm 0.4$ & $4.1-6.12$ & NS \\
\hline $\begin{array}{c}\text { Haemoglobin } \\
\text { g/L }\end{array}$ & $125.3 \pm 13.9$ & $111-139$ & $142.0 \pm 12.0$ & $124-165$ & NS \\
\hline $\begin{array}{c}\text { Leukocytes } \\
10^{9} / \mathrm{L}\end{array}$ & $6.18 \pm 1.3$ & $4.8-7.5$ & $6.2 \pm 1.6$ & $4.17-10.52$ & NS \\
\hline $\begin{array}{c}\text { Platelets } \\
10^{6} / \mathrm{L}\end{array}$ & $212 \pm 58$ & $154-270$ & $227.8 \pm 56.0$ & $133.0-455.0$ & $<0.001$ \\
\hline
\end{tabular}

Unpaired Student's t test was used to evaluate the difference of haematochemical parameters between the two group of Subjects, using GraphPad InStat version 3.06, GraphPad Software statistical package, San Diego California USA. Differences were considered statistically significant when $\mathrm{p}<0.05$. NS $=$ Not significant difference 